PRELIMINARY DELINEATION AND DESCRIPTION OF THE REGIONAL AQUIFERS OF TENNESSEE--CUMBERLAND PLATEAU AQUIFER SYSTEM

By J.V. Brahana, Jo Ann Macy, Dolores Mulderink, and Dawn Zemo

U.S. GEOLOGICAL SURVEY

Open-File Report $82-338$

Prepared in cooperation with the

U.S. ENVIRONMENTAL PROTECTION AGENCY

Nashville, Tennessee 
UNITED STATES DEPARTMENT OF THE INTERIOR

JAMES G. WATT, Secretary

GEOLOGICAL SURVEY

Dallas L. Peck, Director

For additional information write to:

District Chief U.S. Geological Survey A-413 Federal Building U.S. Courthouse Nashville, Tennessee 37203
Copies of this report can be purchased from:

Open-File Services Section Western Distribution Branch U.S. Geological Survey Box 25425, Federal Center Lakewood, Colorado 80225 


\section{CONTENTS}

Abstract 1

Int roduction 1

Geology 2

Hydrology 2

Water quality $\mathbf{3}$

Dr inking-water supplies

Contamination 4

Gurrent and potential hydrocarbon, mineral, and geothemal resource use 4

Summary 4

Selected references 23

\section{ILLUSTRATIONS}

Figure 1. Map showing the areal occurrence of the Amberland Plateau aquifer system and physiographic provinces in Tennessee

2. Map showing generalized structural features

of the Cumberland Plateau aquifer system in Tennessee 7

3. Map showing location of cross-section lines 12

4-7. Regionalized geohydrologic sections showing water quality in the Cumberland Plateau aquifer system:

4. Along 1 ine $A-A^{\prime} 13$

5. Along 1 ine $B-B^{\prime} 14$

6. Along I ine $\mathrm{C}-\mathrm{C}^{\prime} \quad 15$

7. Along line $\mathrm{H}-\mathrm{H}^{\prime} \quad 16$

8. Conceptual model of ground-water occurrence and flow in the Cumber land Plateau aquifer system 18

9. Map showing the distribution of dissolved-solids concentrations in the Cumberland Plateau aquifer system 19

10. Map showing area of use of the Cumberland Plateau aquifer system as a source of drinking-water supplies 20

11. Map showing generalized location of potential coal resources in the Cumberland Plateau aquifer system and potential hydrocarbon resources fron pre-Pennsylvanian rocks

\section{TABLES}

Table 1. Hydrogeology of the formations comprising

the Cumberland Plateau aquifer system

2. Dissolved-solids concentrations from selected wells 10

3. Summary of public drinking-water supplies 21 


\section{FACTORS FOR CON VERTING INCH-POUND UNITS TO INTERNATIONAL SYSTEM OF UNITS (SI)}

For the convenience of readers who may want to use International System of Units (SI), the data may be converted by using the following factors:

Multiply

inch (in.)

foot $(\mathrm{ft})$

foot per mile ( $\mathrm{ft} / \mathrm{mi})$

mile (mi)

square $\mathrm{mile}\left(\mathrm{mi}^{2}\right)$

gallons per minute

(gal/min)
By

25.4

0.3048

0.1894

1.609

2.590

0.06309
To obtain

millimeter $(\mathrm{mm})$

meter $(m)$

meter per kilometer $(\mathrm{m} / \mathrm{km})$

kilometer $(\mathrm{km})$

square kilometer $\left(\mathrm{km}^{2}\right)$

liters per second $(\mathrm{L} / \mathrm{s})$

National Geodetic Vertical Datum of 1929 (NG VD of 1929): A geodetic datum derived from a general adjustment of the first-order level nets of both the United States and Canada, formerly called "Mean Sea Level." 


\title{
PRELIMINARY DELINEATION AND DESCRIPTION OF THE REGIONAL AQUIFERS OF TENNESSEE--CUMBERLAND PLATEAU AQUIFER SYSTEM
}

\author{
By J.V. Brahana, Jo Ann Macy, Dolores Mulderink, and Dawn Zemo
}

\begin{abstract}
The Cumberland Plateau aquifer system consists of Pennisylvanian sandstones, conglomerates, shales, and coals which underlie the Cumberland Plateau in Tennessee. Major water-bearing zones occur within the sandstones and conglomerates in interconnected fractures. The water-bearing formations are separated by shale and siltstone that retard the vertical circulation of ground water. The Pennington Formation serves as the base of this aquifer system and is an effective confining unit.

The Cumberland Plateau aquifer system is an important water source for the Cumberland Plateau. Wells and springs from the aquifer system supply most of the rural domestic and public drinking-water supplies. water from wells drilled into the Cumberland Plateau aquifer system is generally of good to excellent quality. Of the 32 water-quality analyses on file from this aquifer, only 2 had dissolved-solids concentrations greater than 500 milligrams per liter, and about three-fourths had less than 200 milligrams per liter dissolved solids. However, no samples from depths greater than 300 feet below land surface have been recorded. Ground water from locations where the sandstones are buried deeply, such as the Wartburg basin, may contain dissolved-solids concentrations greater than 1,000 milligrams per liter.
\end{abstract}

\section{INTRODUCTION}

The Safe Drinking Water Act (P.L.93-523) includes provisions for the protection of underground sources of drinking water. Specifically, Part C of the Act authorizes the Environmental Protection Agency to establish regulations to insure that injection of contaminants will not endanger existing or potential sources of drinking water. The regulations developed by EPA require that all underground sources of water with less than 10,000 milligrams per liter (mg/L) dissolved solids be designated for protection whether or not they are currently being used as a source of drinking water.

The eight major aquifer systems of Tennessee have been delineated on a regional basis and are characterized by a unique set of hydrologic conditions, as well as a distinguishing water quality. The aquifer systems are commonly separated from one another by confining units or zones in which the vertical hydraulic conductivity is less than in the aquifer system. The hydrologic effectiveness of the confining units is variable and depends on the local geology. In general, the confining units restrict, but do not exclude, flow between aquifers on a regional scale. 
The purpose of this report is to describe the formations that comprise the Cumberland Plateau aquifer system (fig. 1) and to delineate zones within this aquifer system that are actual or potential drinking-water sources. This report provides generalized information on (1) the areal and stratigraphic occurrence of the aquifer and the water within, (2) dissolved-solids content of the ground water, (3) area of ground-water use and potential use, (4) the hydraulic character of the aquifer, (5) the areas of known ground-water contamination, and (6) the known locations of current and potential hydrocarbon, mineral, and geothermal resources in the sequence of geologic formations that includes all of the Pennsylvanian rock units in this area. Formation names used in this report are those of the Tennessee Division of Geology (Miller, 1974) and do not necessarily follow the usage of the U.S. Geological Survey.

\section{GEOLOG Y}

The Cumberland Plateau aquifer system underlies the Cumberland Plateau (fig. 2) and consists of nine geologic rock units of Pennyslvanian age with highly varied permeabilities (table 1). The upper two-thirds of the aquifer system is primarily shale with thin interbedded sandstones, coals, and siltstones. The lower one-third contains fewer shales and thicker sandstone beds that are commonly conglomeratic. The top of the thick, impermeable Pennington Formation is defined as the base for the Cumberland Plateau aquifer system and is an effective regional confining unit (table 2; fig. 2). It is composed of several hundred feet of shale, siltstone, and fine-grained dolomite.

Throughout most of the Plateau, the rocks of the aquifer system are nearly horizontal with a gentle dip of from 20 to 50 feet per mile toward the east. Although essentially undeformed, they are cut by faults in the central and northern parts of the area. Formations of the Cumberland Plateau are separated from the more intensely deformed Valley and Ridge Province to the east by a zone of thrust faulting and steeply dipping rocks marked by the Sequatchie Valley anticline, Walden Ridge, and the Pine Mountain thrust (fig. 2). Lines of section, which are located in figure 3 and shown in figures 4-7, generalize the structural relations of the rocks that comprise this aquifer system.

In addition to unpublished data, the following reports were used to compile the geology: Born and Burwell (1939); Wanless (1946); Stearns (1954); Wilson and others (1956); Hack (1966); Burwell and Milhous (1967a and b); and, Milici and others (1979).

\section{HYDROLOG Y}

Ground water in the Cumberland Plateau aquifer system occurs almost exclusively within the Pennsylvanian sandstones and conglomerates. Although the sandstones have low intergranular permeability, secondary permeability is provided by fractures. Water in these sandstone units is effectively confined and separated by shale and siltstone beds with very low permeability. Almost all the ground water is under artesian pressure, and the water level in many wells rises to within a few feet of land surface (Newcome and Smith, 1958). The sandstone layers are classed as a single hydrologic unit because they exhibit similar hydraulic characteristics and contain water of similar chemical quality. A conceptual model of ground-water occurrence and flow in the Cumberland Plateau aquifer system is shown in figure 8. 
The recharge of the Cumberland Plateau aquifer system is effectively limited to precipitation on the outcrops of the sandstones and conglomerates. Streams intersecting these outcrops may also contribute to recharge. The shale layers retard the downward movement of ground water and there is very little interformational movement from one sandstone to another, except along fractures.

For the most part, ground-water flow in the Cumberland Plateau aquifer system is shallow flow, with water flowing from points of recharge to points of discharge. In addition to providing base flow of streams, ground water also is discharged through springs, which are common in the escarpments bounding this aquifer system and in the walls of many deep, narrow stream valleys, particularly the Sequatchie Valley. Commonly, the springs in the Cumberland Plateau issue from sandstones near their contact with shale beds (fig. 8).

Ground-water movement between the Cumberland Plateau aquifer system and the Valley and Ridge aquifer system is restricted by a zone of faulting and structural deformation between the two systems. In areas where the water-bearing formations are deeply buried, such as the Wartburg Basin, movement of the water is thought to be very restricted.

Newcome and Smith (1958), Wilson (1965), and Zurawski (1978) were used as the primary hydrology references for this report.

\section{WATER QUALITY}

Chemical analyses of water from wells drilled into the Cumberland Plateau aquifer system generally indicate good to excellent quality throughout the area of occurrence of the aquifer. Of the 32 water-quality analyses from this aquifer, only two had dissolvedsolids concentrations greater than $500 \mathrm{mg} / \mathrm{L}$, and three fourths had dissolved solids less than $200 \mathrm{mg} / \mathrm{L}$. Two of the more common characteristics of ground water in the Cumberland Plateau are high iron content (typically several milligrams per liter) and the presence of hydrogen sulfide. Water generally is calcium bicarbonate type, with pH below 7.0. Two chemical analyses of water from the northern part of this aquifer system have reported dissolved-solids concentrations greater than $500 \mathrm{mg} / \mathrm{L}$. Figure 9 shows the areal distribution of dissolved solids in the aquifer system and table 2 shows the variation of dissolved solids by depth and water-bearing formation.

It should be noted that all analyses reported from the Cumberland Plateau aquifer system are of water from wells less than 300 feet deep. Although it has not been confirmed by data, it is suspected that the dissolved solids of the water increases in areas where the sandstones are buried by more than 500 feet of shales. Deeply buried sandstones in the Wartburg Basin may contain water with dissolved solids in the range of 1,000 to $10,000 \mathrm{mg} / \mathrm{L}$, but this remains to be documented. Nevertheless, because the water is generally of good quality, this aquifer system does not qualify for deep-well injection.

Water-quality data are based on these reports: DeBuchananne and Richardson (1956), Newcome and Smith (1958), Wilson (1965); and Sprinkle (1977). 


\section{DRINKING -WATER SUPPLIES}

The Cumberland Plateau aquifer system is an important source of water for the Cumberland Plateau. Wells and springs from this aquifer system supply most of the domestic and public supplies of drinking water used (fig. 10; table 3). Data indicate that ground water is a vailable throughout the Plateau, but the quantity is highly variable from place to place and locally may not be large enough to supply large public needs.

\section{CONTAMINATION}

The Cumberland Plateau aquifer system has no documented sites of contamination; however, the area is a site of intensive oil and gas exploration in Tennessee, and saline water from deeper depths has entered into the shallow zones of this aquifer system (Rima, Chase and Myers, 1971; Miller and Maher, 1972). No part of this regional aquifer qualifies for receiving injected underground waste.

\section{CURRENT AND POTENTIAL HYDROCARBON, MINERAL, AND GEOTHERMAL RESOURCE USE}

Coal has been mined commercially in the Cumberland Plateau since 1830, reaching peak production in the 1950's with the increase of mechanization and strip mining (fig. 11). Since then, production has declined but remains relatively high at more than 10 million tons annually. Although coal mining, both strip and underground, can have a deleterious impact on surface water, there is no documented information available to indicate that coal mining has impacted ground-water quality.

Intensive oil and gas exploration occurs in the Cumberland Plateau (fig. 11), but these wells are drilled and cased to depths below the Pennington Formation. If these wells are improperly cased and sealed, however, contamination by seepage may result.

Luther (1959), May and Maher (1979), and Tennessee Department of Labor (1981) are the sources of information for this section of the report.

\section{SUMMARY}

The Cumberland Plateau aquifer system derives its name from its area of occurrence, the Cumberland Plateau in the east-central part of the State. It is an important source of water, providing many towns and most rural areas with drinking water.

The Cumberland Plateau aquifer system consists of interbedded sandstones, conglomerates, siltstones, shales, and coals of Pennsylvanian age. Major water-bearing zones occur within the sandstones and conglomerates in interconnected fractures. The waterbearing sandstone layers are separated from one another by nearly horizontal shale and siltstone layers that retard the vertical circulation of ground water. The Pennington Formation, which is the base of the aquifer system, is an effective regional confining unit. 
Coal has been mined in the Cumberland Plateau since 1830. Intensive oil and gas exploration also occurs in this area. If these wells are not cased and sealed to the base of the Pennington Formation, contamination of the Cumberland Plateau aquifer system may result from seepage of saline water from deeper depths into the shallow zones of this aquifer system.

Because water quality in the aquifer system is generally good to excellent and because the aquifer is used throughout its area of occurrence in Tennessee, the Cumberland Plateau aquifer system is classed as an underground drinking-water source under the criteria defined by the law, and as such does not qualify for receiving injected wastes. 


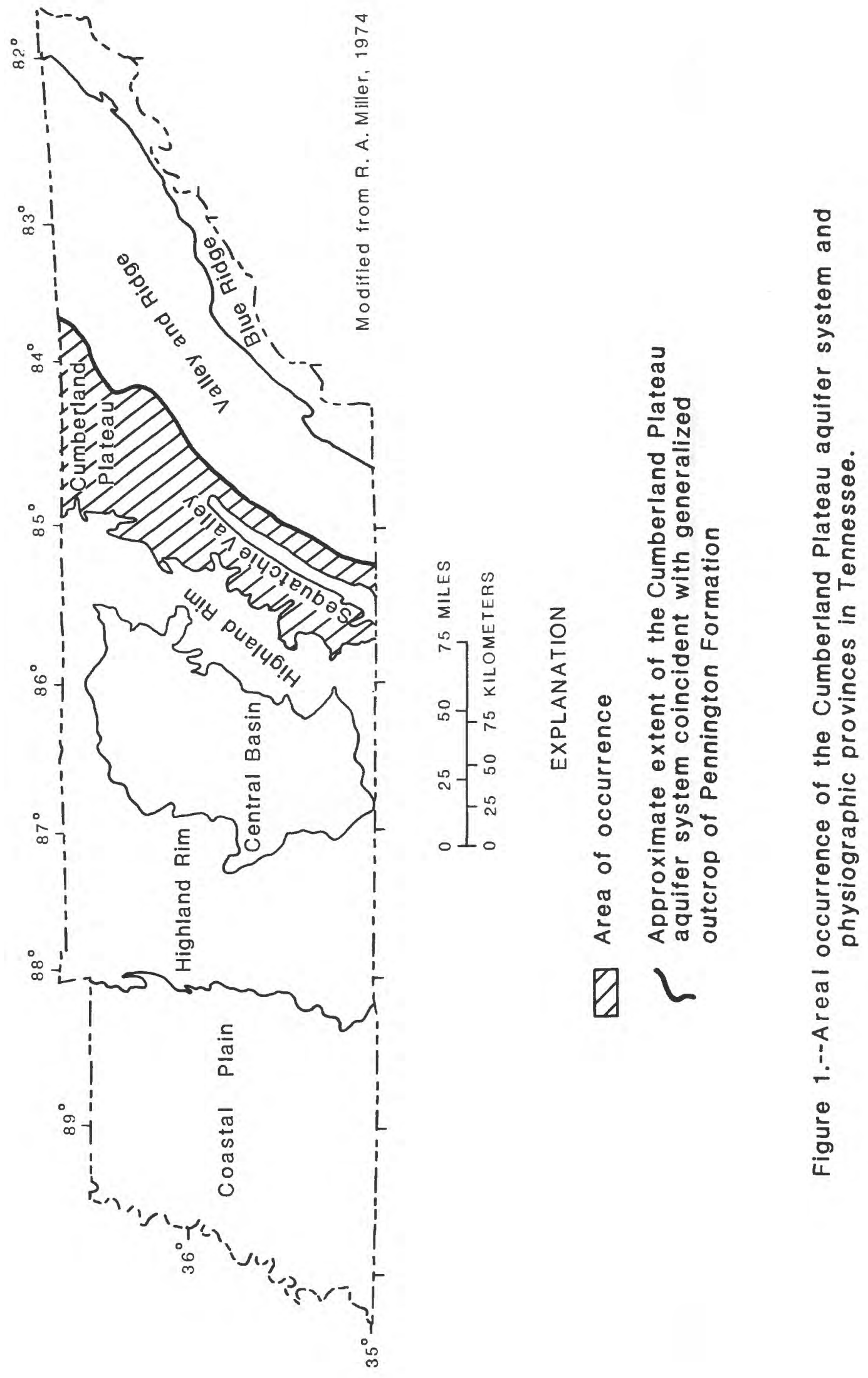



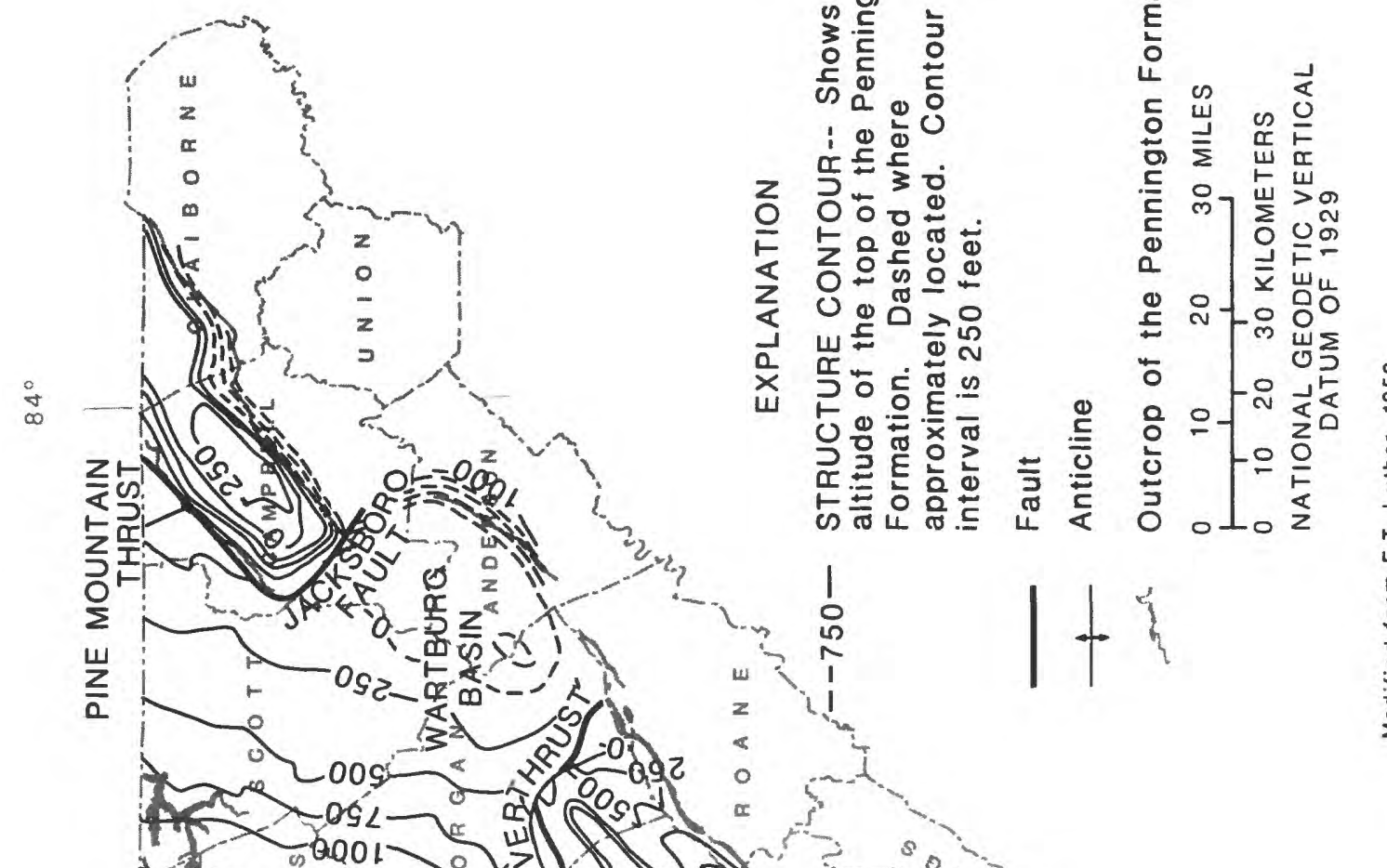

ఖं

讪尔

यं

E⿰冫欠

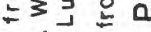

앙 文

Ðu

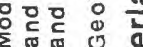
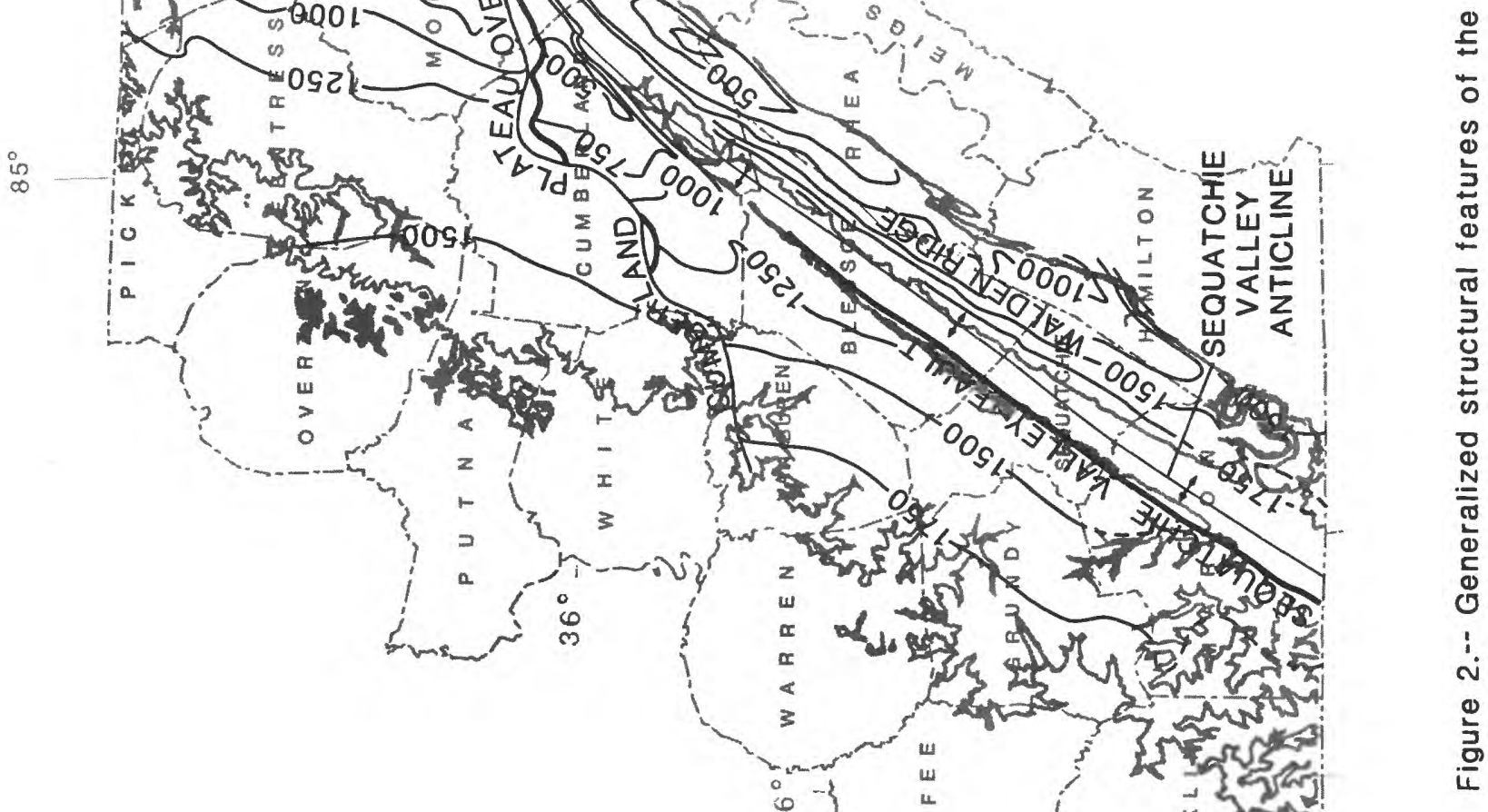


\begin{tabular}{|c|c|c|c|c|c|c|}
\hline ఏ్ర & $\frac{0}{2}$ & 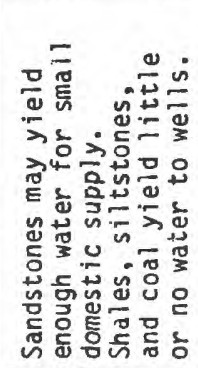 & 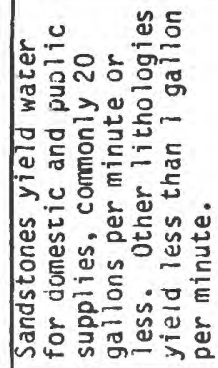 & 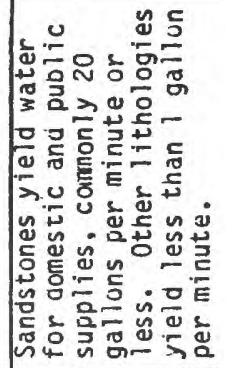 & 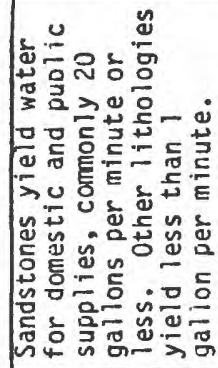 & 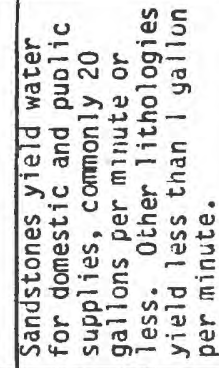 \\
\hline 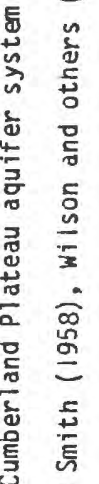 & 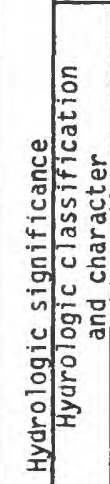 & 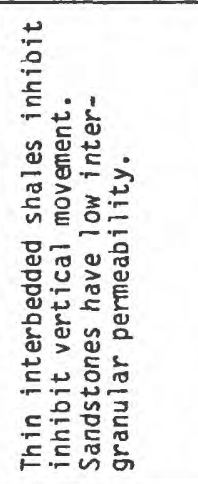 & 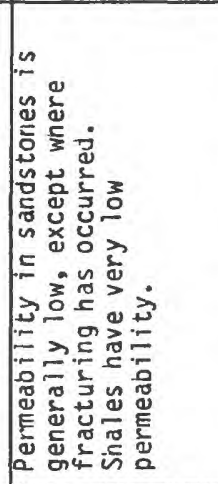 & 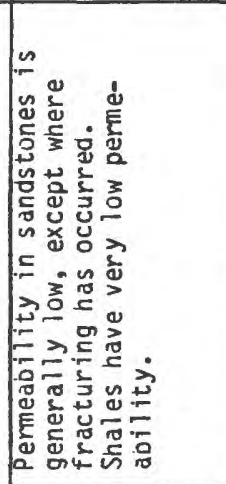 & 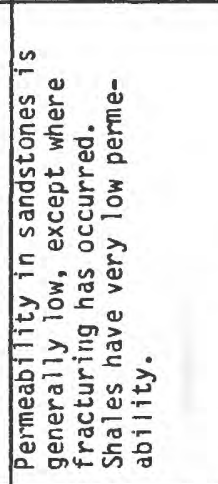 & 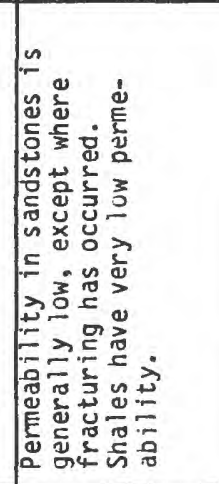 \\
\hline 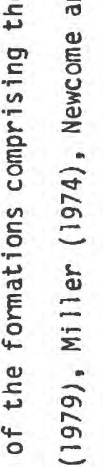 & 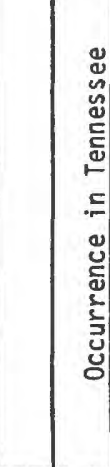 & 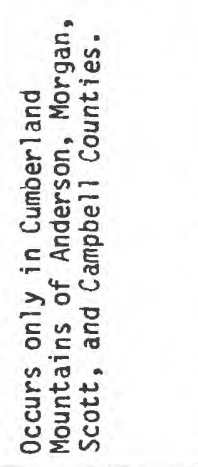 & 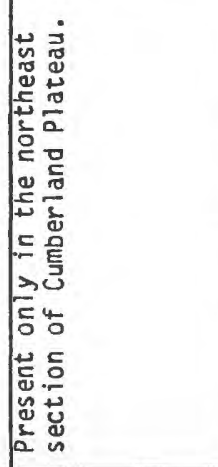 & 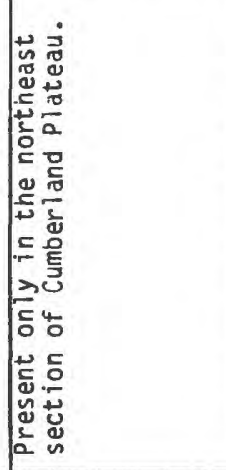 & 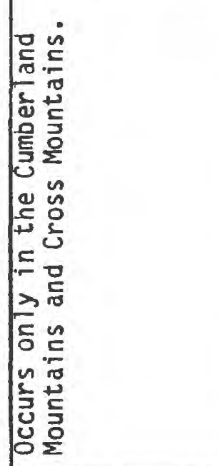 & 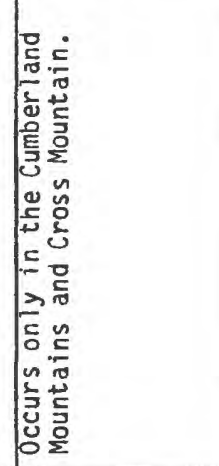 \\
\hline 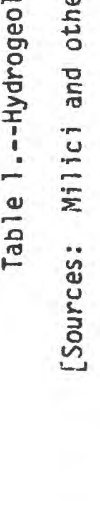 & 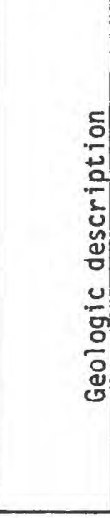 & 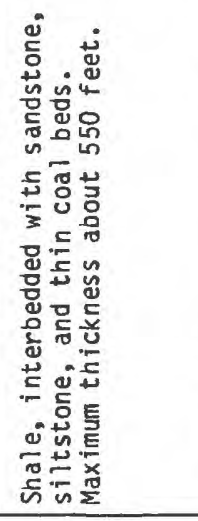 & 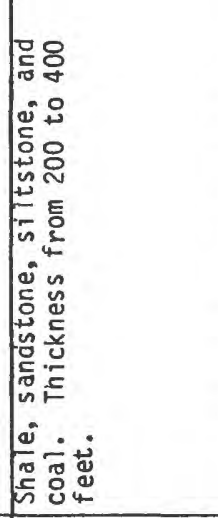 & 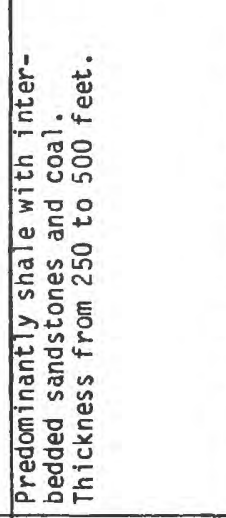 & 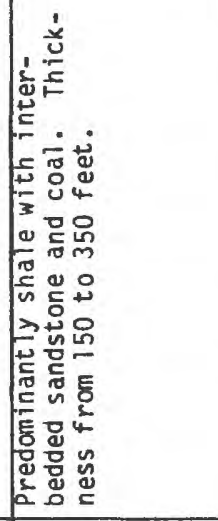 & 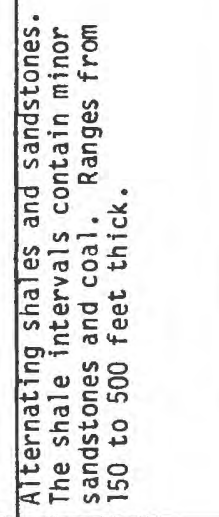 \\
\hline & 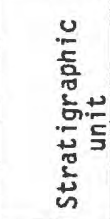 & 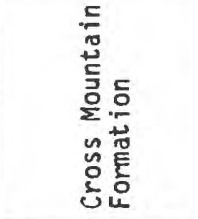 & 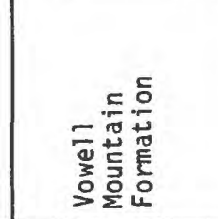 & 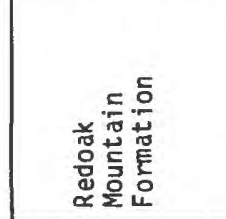 & 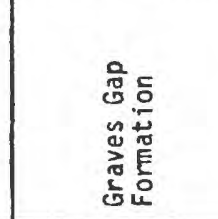 & 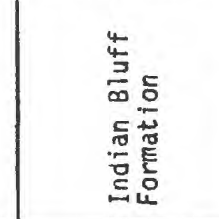 \\
\hline & Sə!ฺəS & \multicolumn{5}{|c|}{ วІpp!W } \\
\hline & шә75אS & \multicolumn{5}{|c|}{ NYINYATASNNGd } \\
\hline
\end{tabular}




\begin{tabular}{|c|c|c|c|c|}
\hline 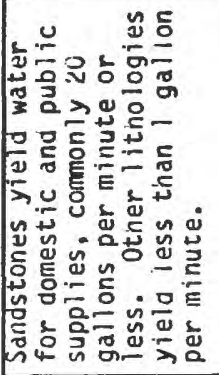 & 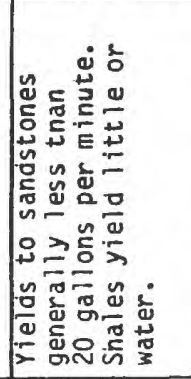 & 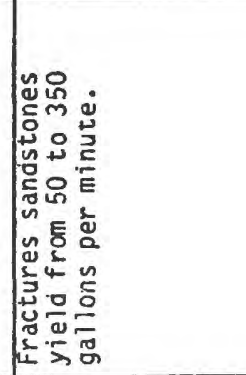 & 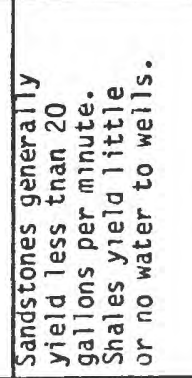 & 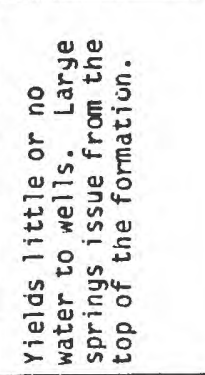 \\
\hline 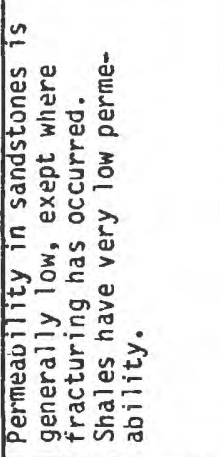 & 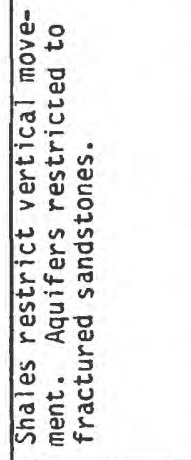 & 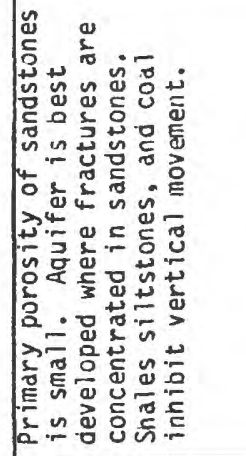 & 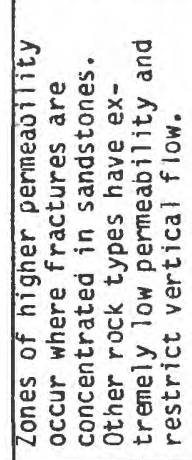 & 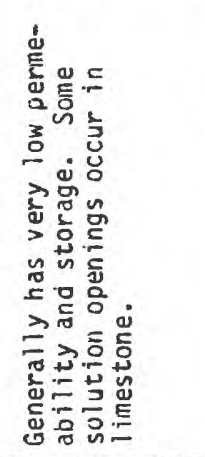 \\
\hline 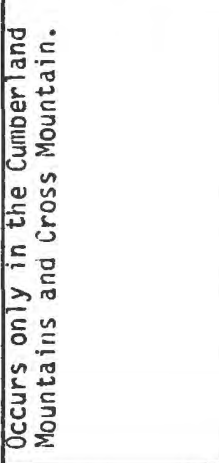 & 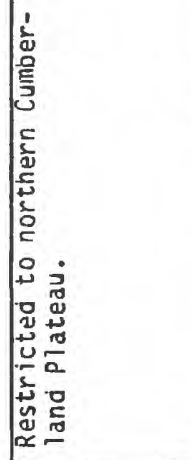 & 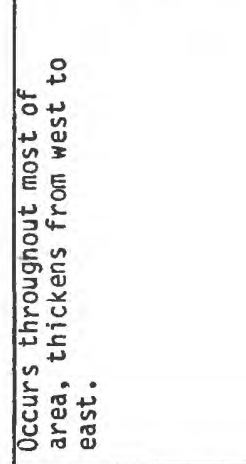 & 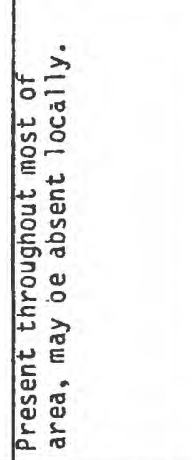 & 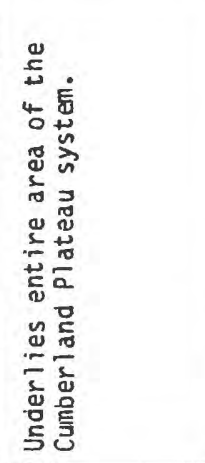 \\
\hline 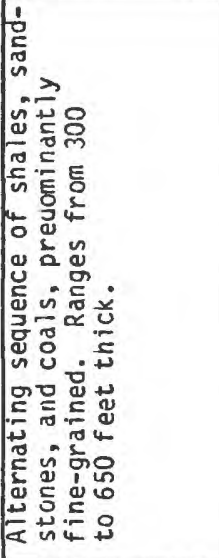 & 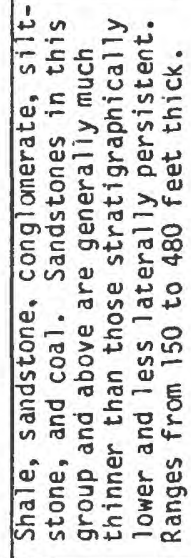 & 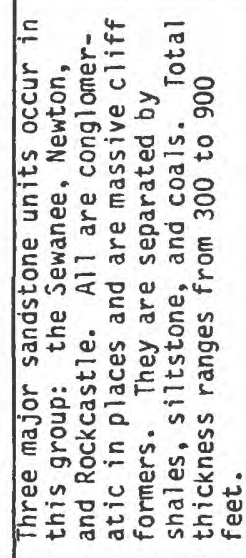 & 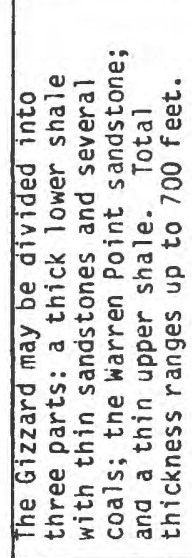 & 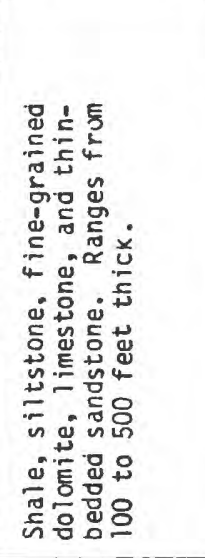 \\
\hline 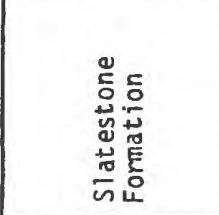 & 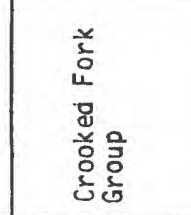 & 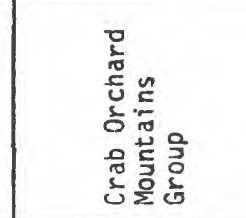 & 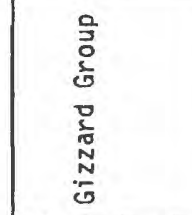 & 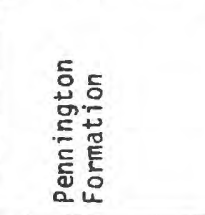 \\
\hline \multicolumn{2}{|c|}{ әІрр!W рие Аәмоך } & \multicolumn{2}{|c|}{ Іәмот } & Jəddn \\
\hline \multicolumn{4}{|c|}{ NYINYATASNNZd } & NGIddISSISSIW \\
\hline
\end{tabular}


Table 2.--Dissolved-solids concentrations from selected wells

[Data source codes: 1, Newcome and Smith, 1958; 2, Sprink1e, 1977; 3, DeBuchananne and Richardson, 1956; 4, USGS unpublished data]

\begin{tabular}{|c|c|c|c|c|c|c|}
\hline County & Location & $\begin{array}{l}\text { Well } \\
\text { No. }\end{array}$ & $\begin{array}{l}\text { Well } \\
\text { depth, } \\
\text { in feet }\end{array}$ & Aquifer & $\begin{array}{l}\text { Dissolved } \\
\text { solids } \\
\text { concentra- } \\
\text { tions, in } \\
\text { milligrams } \\
\text { per liter } \\
\end{array}$ & $\begin{array}{l}\text { Data } \\
\text { source }\end{array}$ \\
\hline Anderson & $\begin{array}{l}\text { Stainville } \\
\text { Rosedale School } \\
\text { Beech Grove }\end{array}$ & $\begin{array}{l}A n: H-11 \\
A n: H-12 \text { (6) } \\
\text { An:J-21 }\end{array}$ & $\begin{array}{l}103 \\
100 \\
200\end{array}$ & $\begin{array}{l}\text { Slatestone } \mathrm{Fm} l \\
\text { Slatestone } \mathrm{Fm} \\
\text { Crooked Fork Gp } 1\end{array}$ & $\begin{array}{r}79 \\
219 \\
54\end{array}$ & $\begin{array}{l}3 \\
2 \\
4\end{array}$ \\
\hline \multirow[t]{2}{*}{ Bledsoe } & Pikeville & $B 1: L-11(17)$ & 38 & $\begin{array}{l}\text { Crab Orchard } \\
\text { Mountains Group }\end{array}$ & 76 & 1 \\
\hline & Pikeville & 22 & 141 & $\begin{array}{l}\text { Crab Orchard } \\
\text { Mountains Group }\end{array}$ & 124 & 1 \\
\hline Campbel1 1 & Jellico & 4 & 194 & Crooked Fork Gp & 538 & 1 \\
\hline Claiborne & Clairfield & $1-4$ & 50 & Crooked Fork Gp & 182 & 1 \\
\hline Cumberl and & Crossville & 1 & 85 & $\begin{array}{l}\text { Crab Orchard } \\
\text { Mountains Group }\end{array}$ & 85 & 1 \\
\hline \multirow[t]{3}{*}{ Fentress } & Armathwaite & 1 & 95 & $\begin{array}{l}\text { Crab Orchard } \\
\text { Mountains Group }\end{array}$ & 130 & 1 \\
\hline & Grimsley & $3-1$ & 238 & $\begin{array}{l}\text { Crab Orchard } \\
\text { Mountains Group }\end{array}$ & 287 & 1 \\
\hline & Pall Mall & 78 & 62 & $\begin{array}{l}\text { Crab Orchard } \\
\text { Mountains Group }\end{array}$ & 140 & 1 \\
\hline Frank 1 in & Sewanee & 6 & 57 & $\begin{array}{l}\text { Crab Orchard } \\
\text { Mountains Group }\end{array}$ & 26 & 1 \\
\hline \multirow[t]{2}{*}{ Grundy } & Tracy City & 2 & 125 & $\begin{array}{l}\text { Crab Orchard } \\
\text { Mountains Group }\end{array}$ & 109 & 1 \\
\hline & Palmer & Gy:G-11(6) & 40 & $\begin{array}{l}\text { Crab Orchard } \\
\text { Mountains Group }\end{array}$ & 42 & 1 \\
\hline \multirow[t]{2}{*}{ Hamilton } & Chattanooga & 2 & 60 & $\begin{array}{l}\text { Crab Orchard } \\
\text { Mountains Group }\end{array}$ & 102 & 1 \\
\hline & Soddy & 8 & 75 & $\begin{array}{l}\text { Crab Orchard } \\
\text { Mountains Group }\end{array}$ & 19 & 1 \\
\hline
\end{tabular}


Table 2.--Dissolved-solids concentrations from selected wells--Continued

\begin{tabular}{|c|c|c|c|c|c|c|}
\hline County & Location & $\begin{array}{l}\text { Well } \\
\text { No. }\end{array}$ & $\begin{array}{c}\text { Well } \\
\text { depth, } \\
\text { in feet }\end{array}$ & Aquifer & $\begin{array}{l}\text { Dissolved } \\
\text { solids } \\
\text { concentra- } \\
\text { tions, in } \\
\text { milligrams } \\
\text { per liter }\end{array}$ & $\begin{array}{l}\text { Data } \\
\text { source }\end{array}$ \\
\hline \multirow[t]{3}{*}{ Marion } & Monteagle & 2 & 120 & $\begin{array}{l}\text { Crab Orchard } \\
\text { Mountains Group }\end{array}$ & 56 & 1 \\
\hline & Whitwell & 14 & 260 & $\begin{array}{l}\text { Crab Orchard } \\
\text { Mountains Group }\end{array}$ & 77 & 1 \\
\hline & Whitwell & 29 & 185 & $\begin{array}{l}\text { Crab Orchard } \\
\text { Mountains Group }\end{array}$ & 110 & 1 \\
\hline \multirow[t]{2}{*}{ Morgan } & Sunbright & 15 & 100 & Crab Orchard & 208 & 1 \\
\hline & Wartburg & 16 & 50 & $\begin{array}{l}\text { Crab Orchard } \\
\text { Mountains Group }\end{array}$ & 154 & 1 \\
\hline Overton & Cliff Springs & 4 & 90 & $\begin{array}{l}\text { Crab Orchard } \\
\text { Mountains Group }\end{array}$ & 52 & 1 \\
\hline \multirow[t]{2}{*}{ Putnam } & Monterey & $P m: M-22(1-1)$ & 150 & $\begin{array}{l}\text { Crab Orchard } \\
\text { Mountains Group }\end{array}$ & 211 & 1 \\
\hline & Monterey & & 145 & $\begin{array}{l}\text { Crab Orchard } \\
\text { Mountains Group }\end{array}$ & 151 & 2 \\
\hline Rhea & Dayton & $\operatorname{Re}: F-16(6)$ & 120 & $\begin{array}{l}\text { Crab Orchard } \\
\text { Mountains Group }\end{array}$ & 57 & 1 \\
\hline \multirow[t]{2}{*}{ Scott } & Huntsville & 3 & 90 & $\begin{array}{l}\text { Crooked Fork } \\
\text { Group }\end{array}$ & 1820 & 1 \\
\hline & $\begin{array}{l}\text { Glenmary } \\
\text { Huntsville }\end{array}$ & $\begin{array}{r}5 \\
10\end{array}$ & $\begin{array}{l}85 \\
50\end{array}$ & $\begin{array}{l}\text { Crooked Fork Gp } \\
\text { Slatestone Fm }\end{array}$ & $\begin{array}{r}242 \\
42\end{array}$ & $\begin{array}{l}1 \\
1\end{array}$ \\
\hline \multirow[t]{2}{*}{ Sequatchie } & Dunlap & 11 & 71 & $\begin{array}{l}\text { Crab Orchard } \\
\text { Mountains Group }\end{array}$ & 102 & 1 \\
\hline & Cagle & 8 & & $\begin{array}{l}\text { Crab Orchard } \\
\text { Mountains Group }\end{array}$ & 199 & 2 \\
\hline Van Buren & Spencer & $V b: E-11(3)$ & 112 & $\begin{array}{l}\text { Crab Orchard } \\
\text { Mountains Group }\end{array}$ & 87 & 1 \\
\hline White & Bon Air & 7 & 71 & $\begin{array}{l}\text { Crab Orchard } \\
\text { Mountains Group }\end{array}$ & 25 & 1 \\
\hline
\end{tabular}

lCalculated from major constitutents 


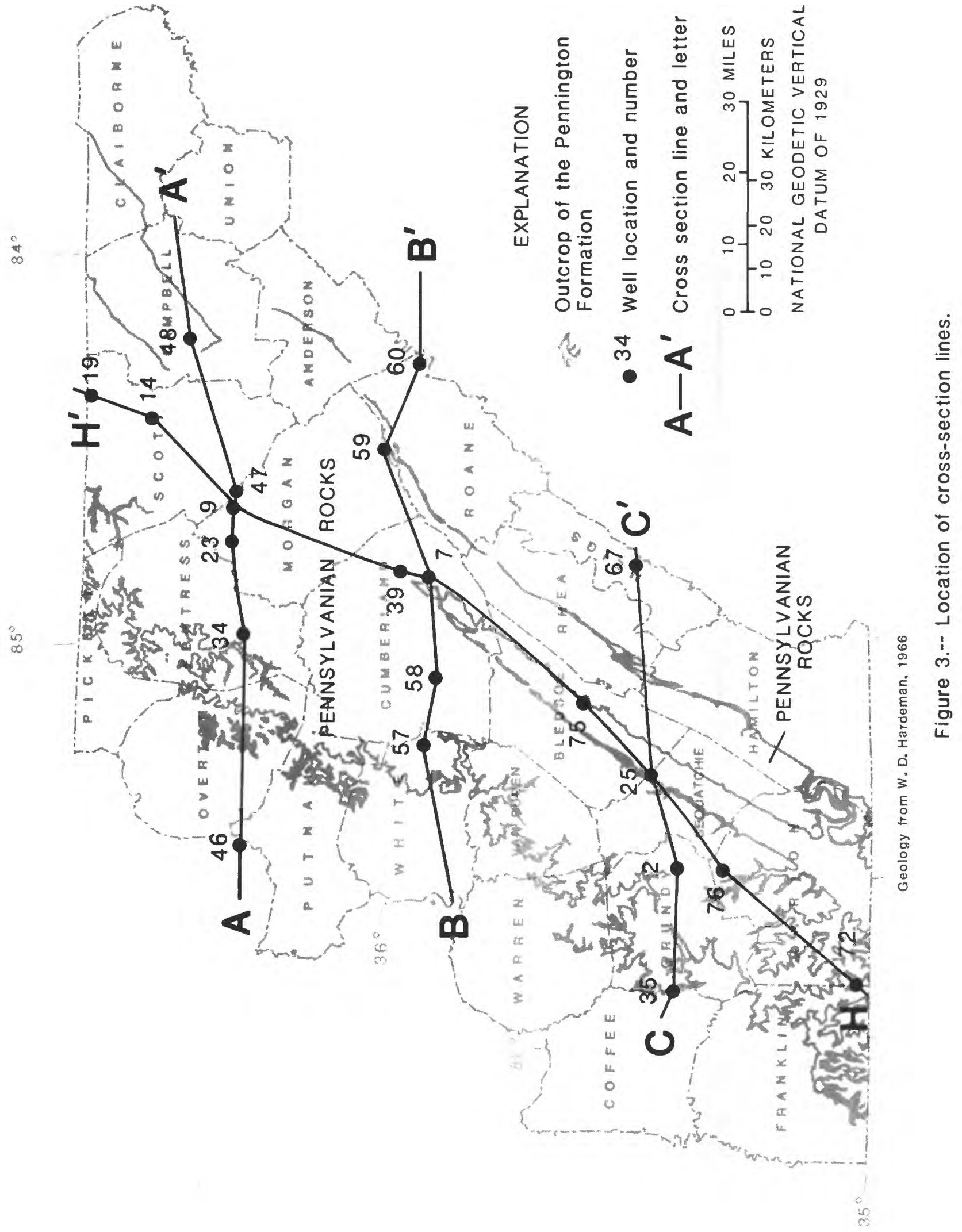




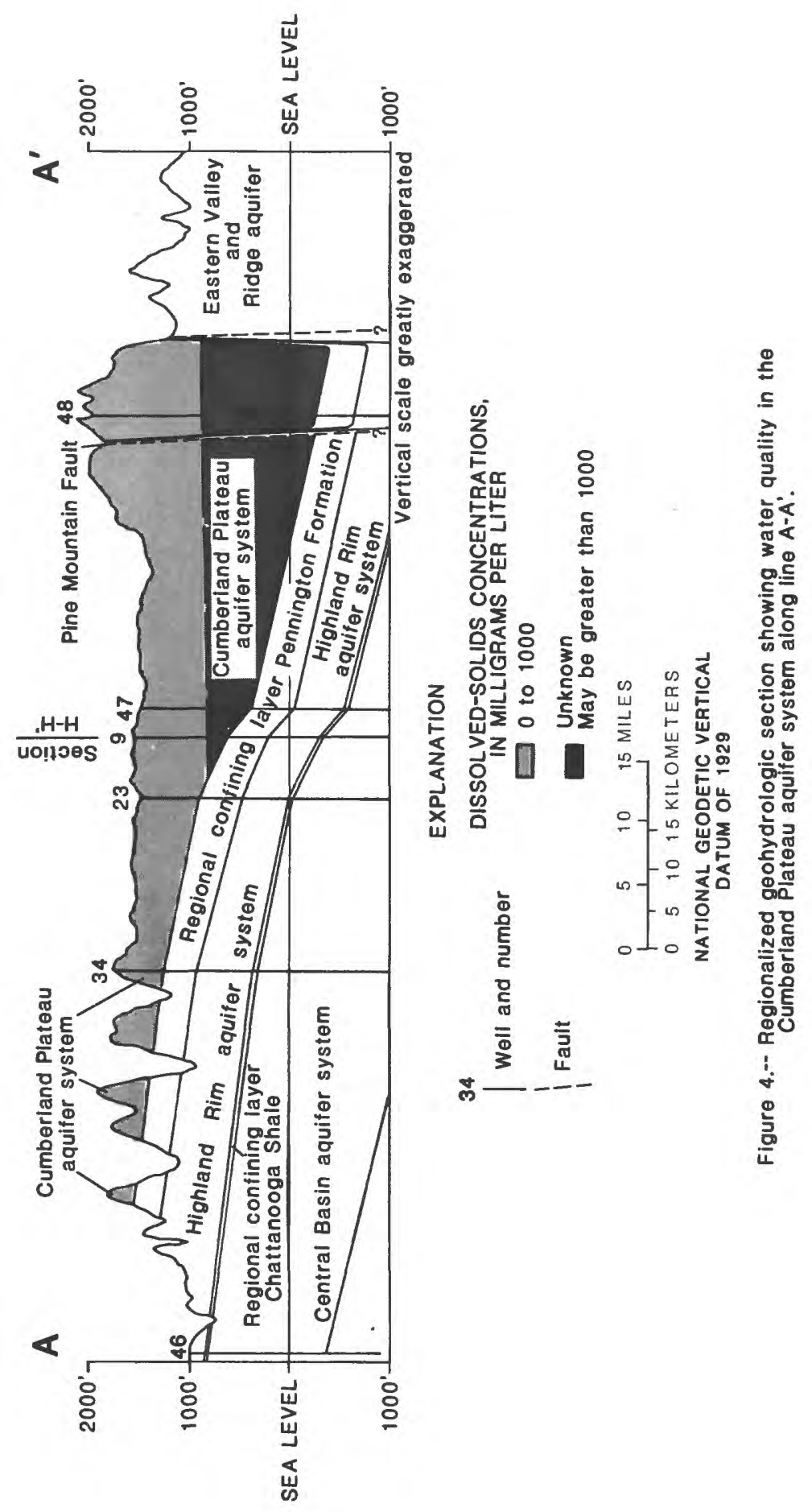




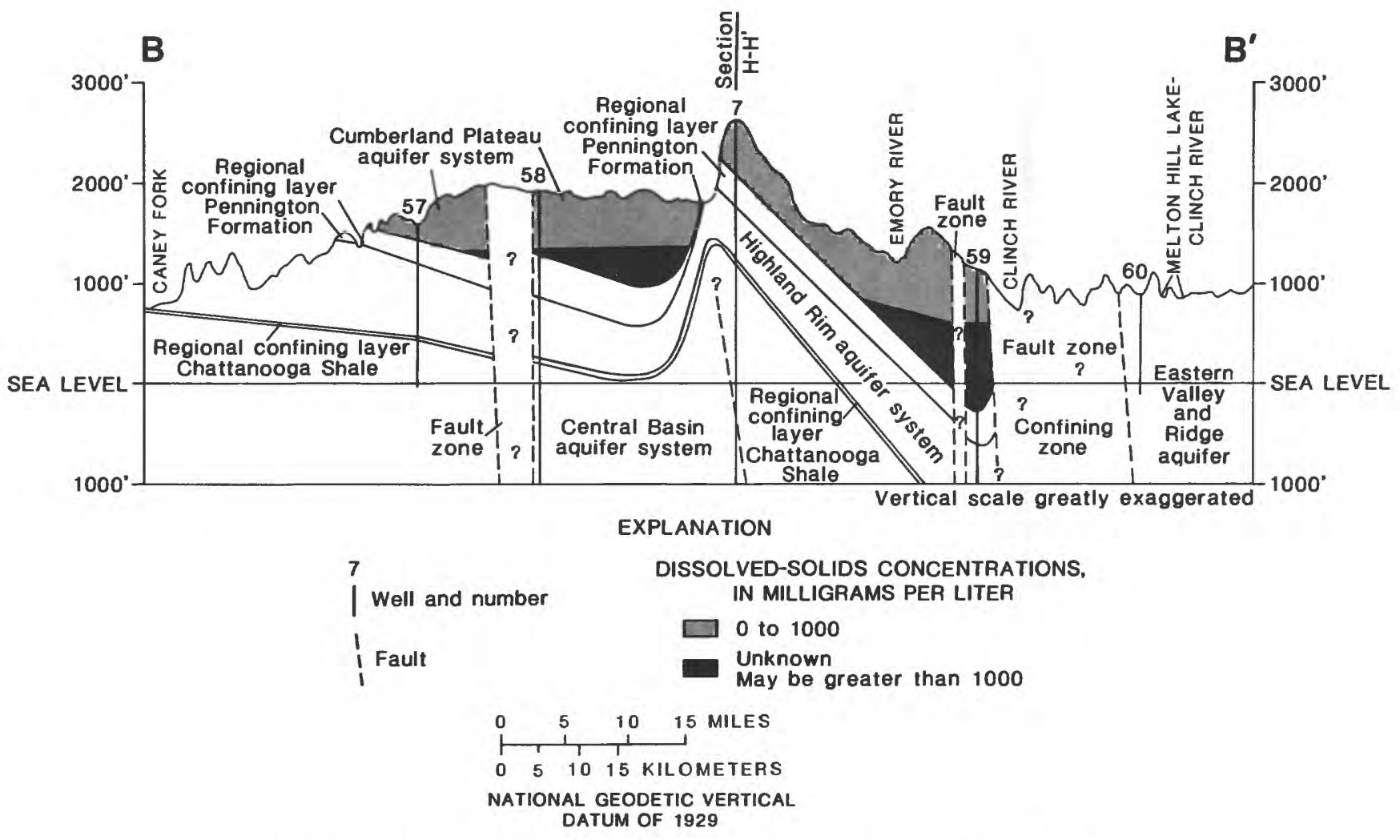

Figure 5.-- Regionalized geohydrologic section showing water quality in the Cumberland Plateau aquifer system along line B-B'. 


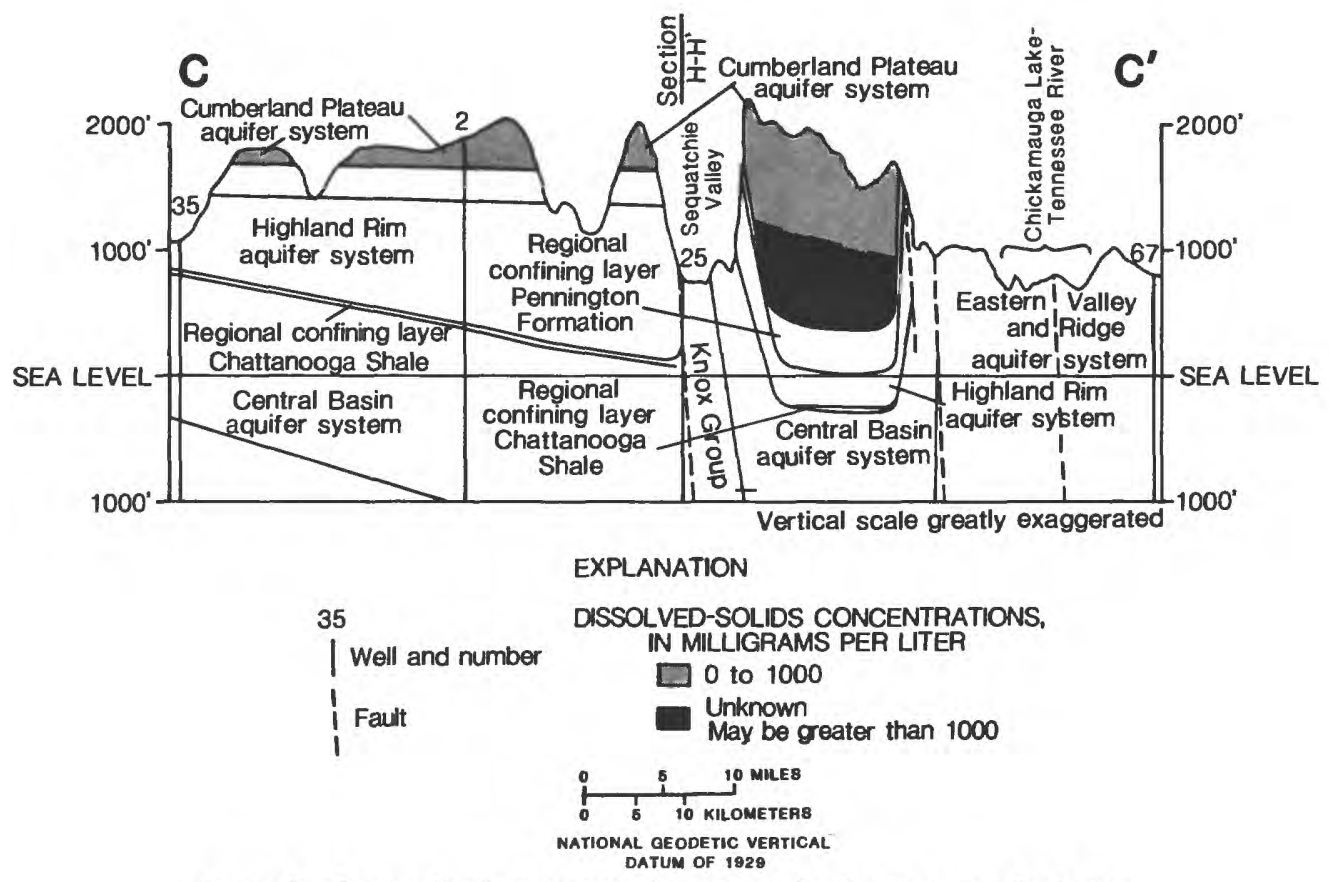

Figure 6.-- Regionalized geohydrologic section showing water quality in the Cumberland Plateau aquifer system along line C-C: 


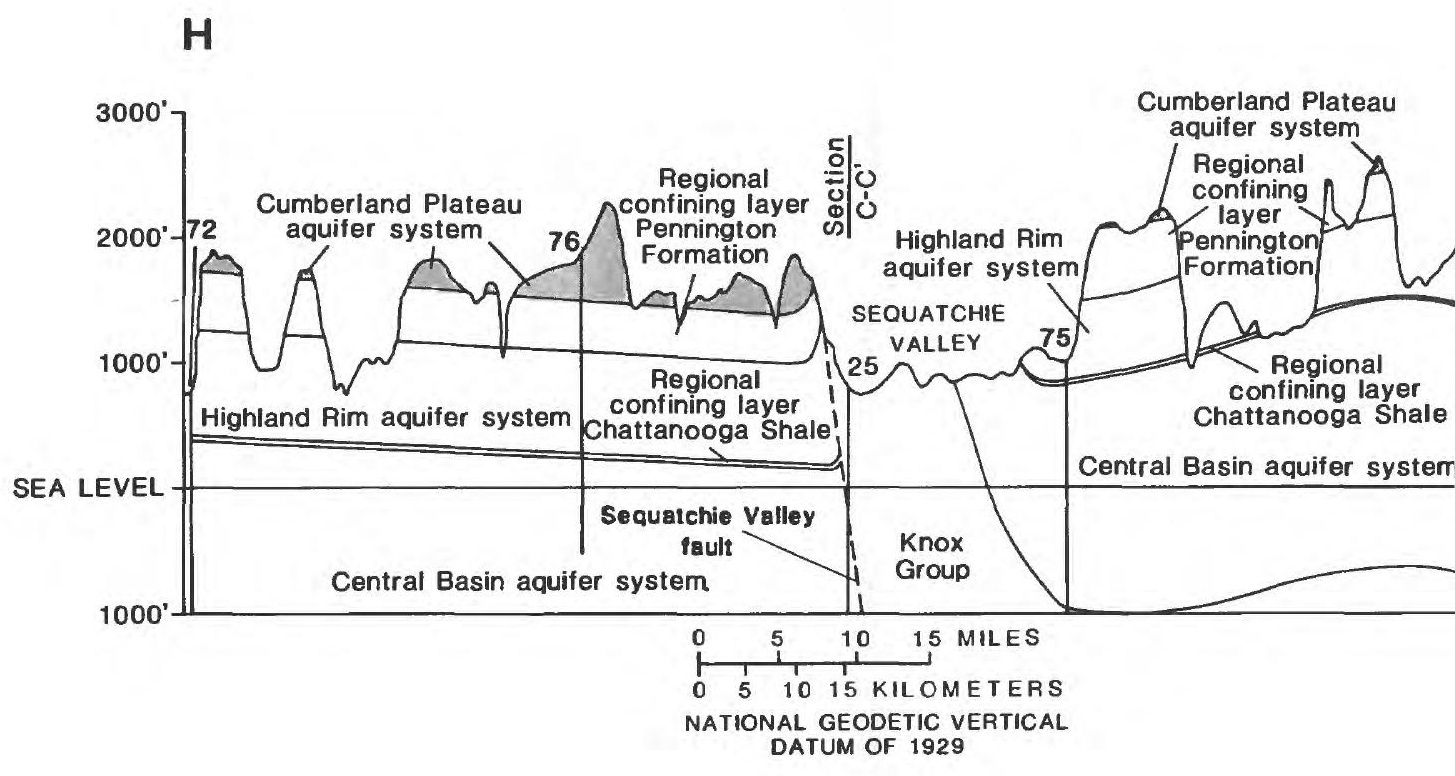

Figure 7.-- Regionalized geohydrologic section showing water quality in the 


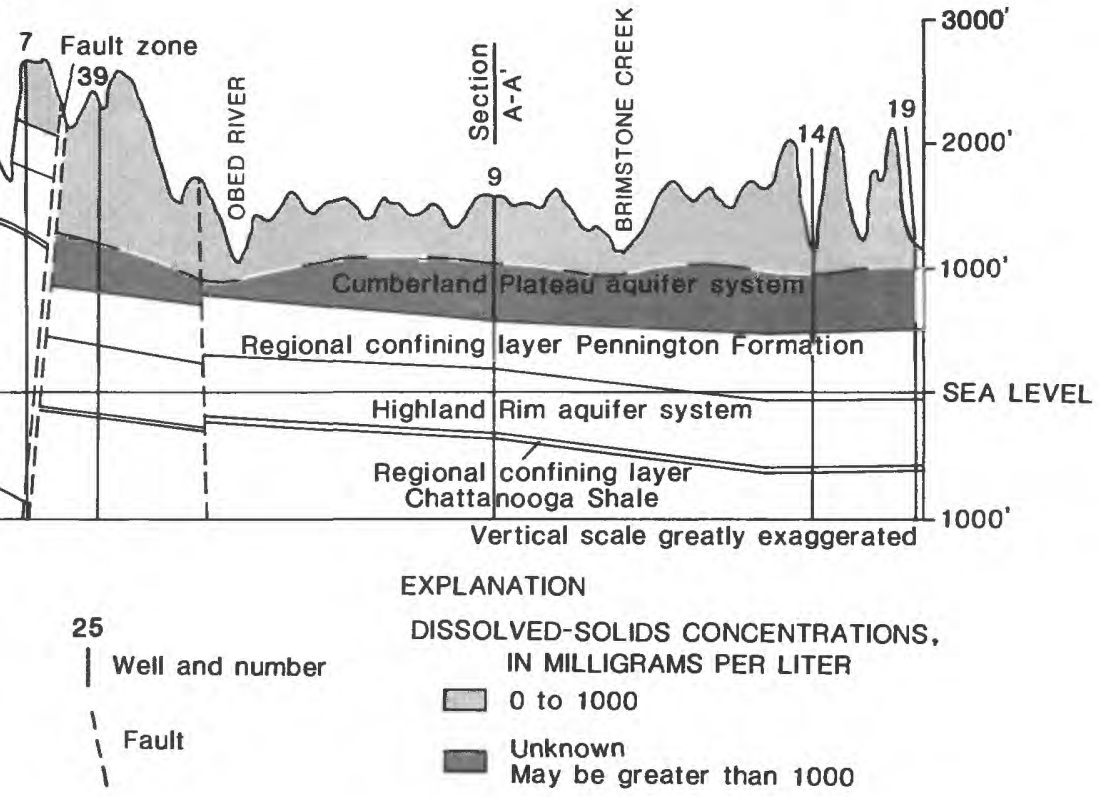

iumberland Plateau aquifer system along line $\mathrm{H}-\mathrm{H}^{\prime}$. 


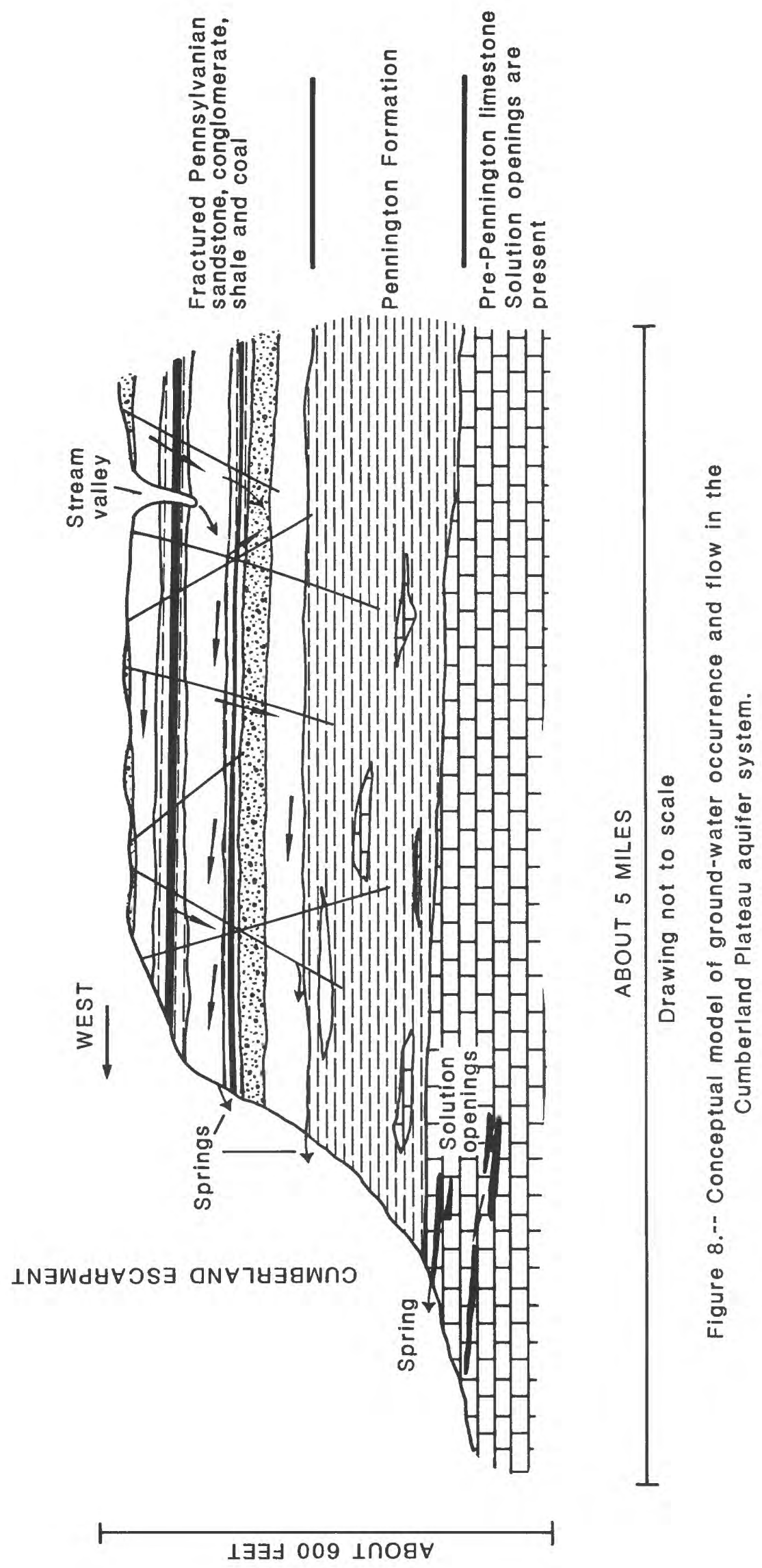




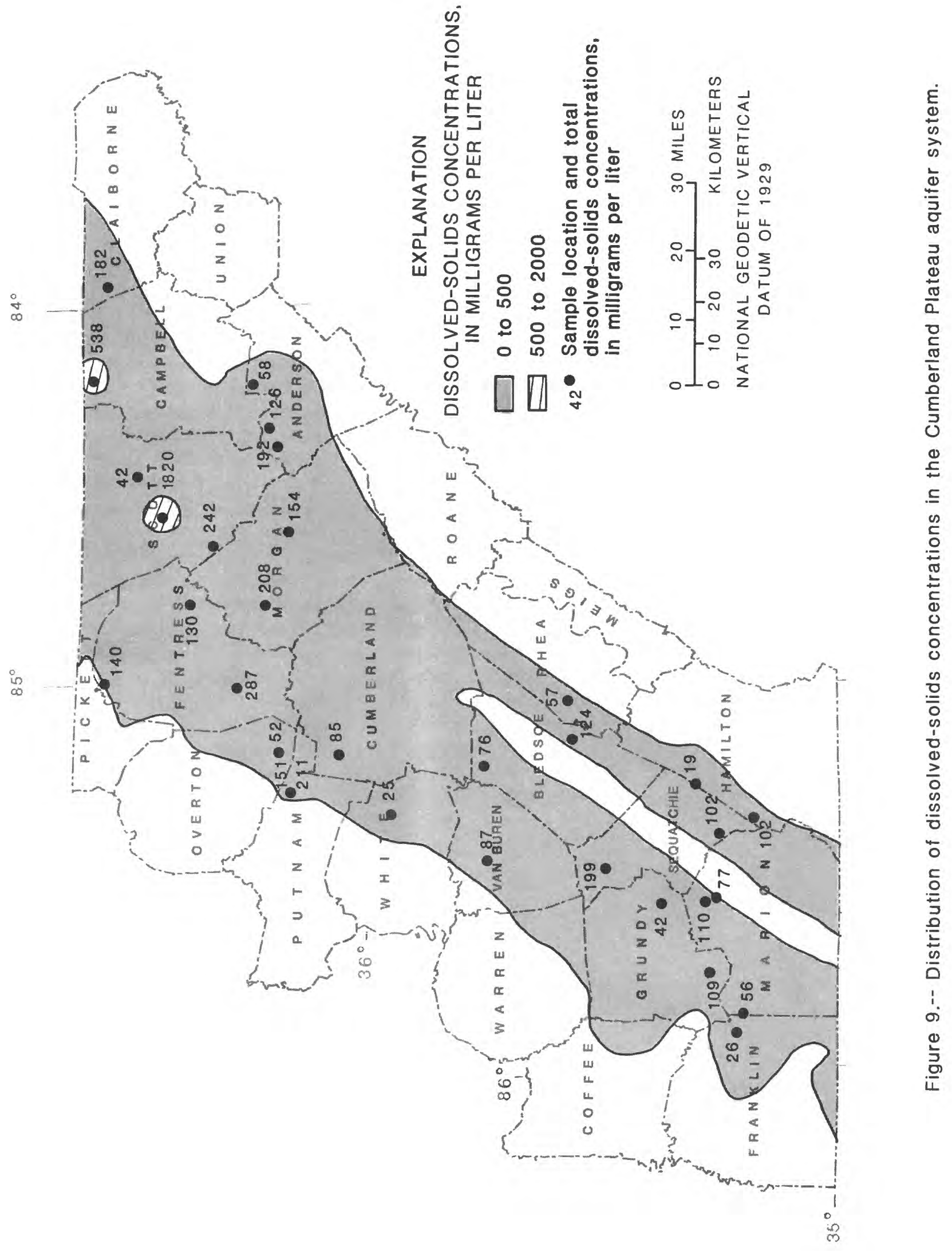




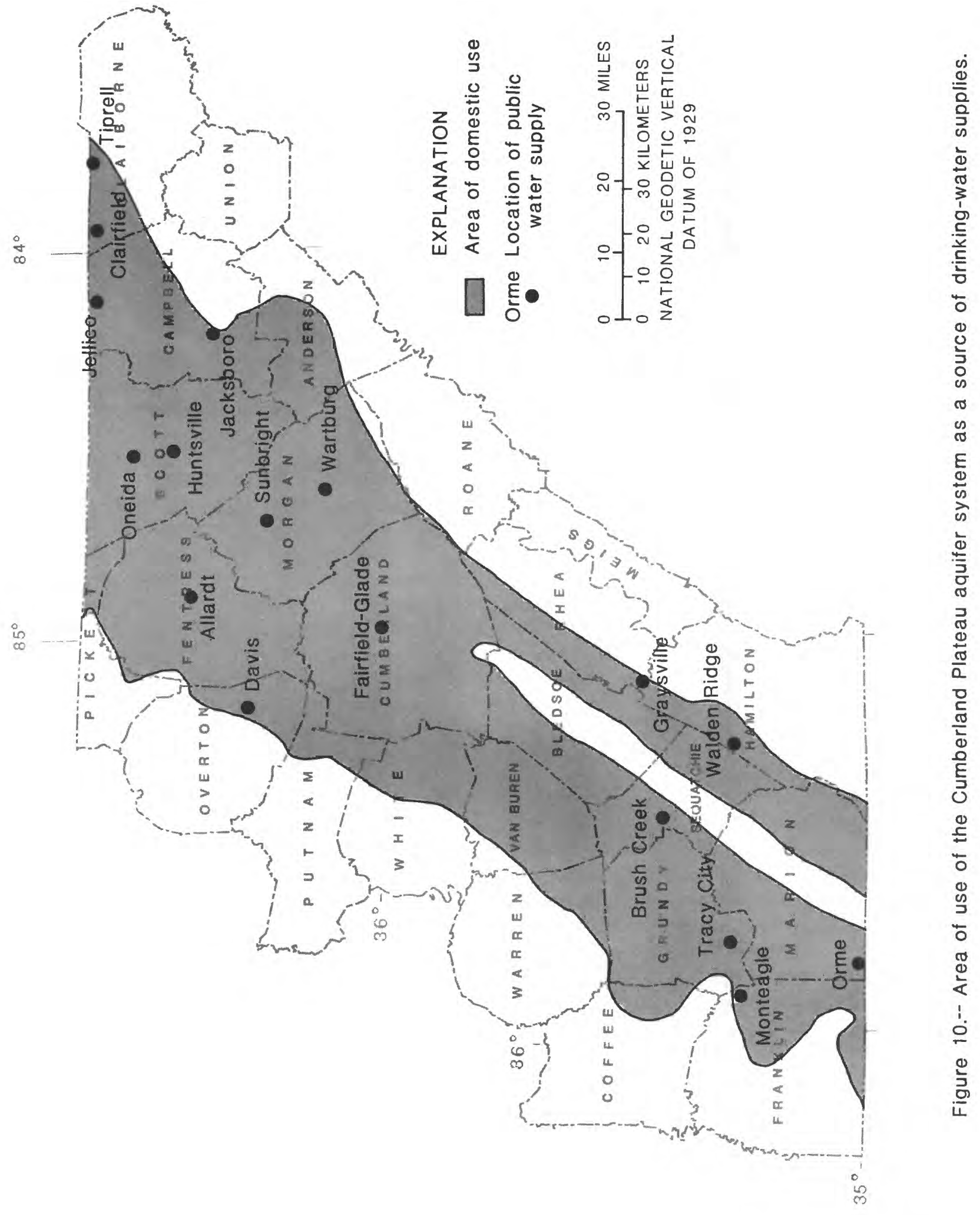


Table 3.--Summary of public drinking-water supplies

[Data Source Codes: 1, Tennessee Comprehensive Joint water and Related Land Resources Planning, Tennessee Division of Water Resources; 2, Tennessee Division of Water Quality Control; 3, Tennessee Division of Water Resources ]

\begin{tabular}{llc}
\hline \multicolumn{1}{c}{ System } & County & Data Source \\
\hline Allardt & Fentress & 2,3 \\
Brush Creek & Sequatchie & 2 \\
Clairfield & Claiborne & 2 \\
Davis & Overton & 2 \\
Fairfield-Glade & Cumberland & 1 \\
Graysville & Rhea & 2 \\
Huntsville U.D. & Scott & 2 \\
Jacksboro & Campbel1 & 3 \\
Jellico & Campbel1 & 1,2 \\
Monteagle Rural U.D. & Grundy & 2 \\
Oneida & Scott & 2 \\
Orme & Marion & 2 \\
Plateau U.D. (Wartburg) & Morgan & 2,3 \\
Sunbright & Morgan & 2 \\
Tipprell & Claiborne & 2 \\
Tracy City & Grundy & 2 \\
Walden Ridge U.D. & Hamilton & 2 \\
& & \\
\hline
\end{tabular}




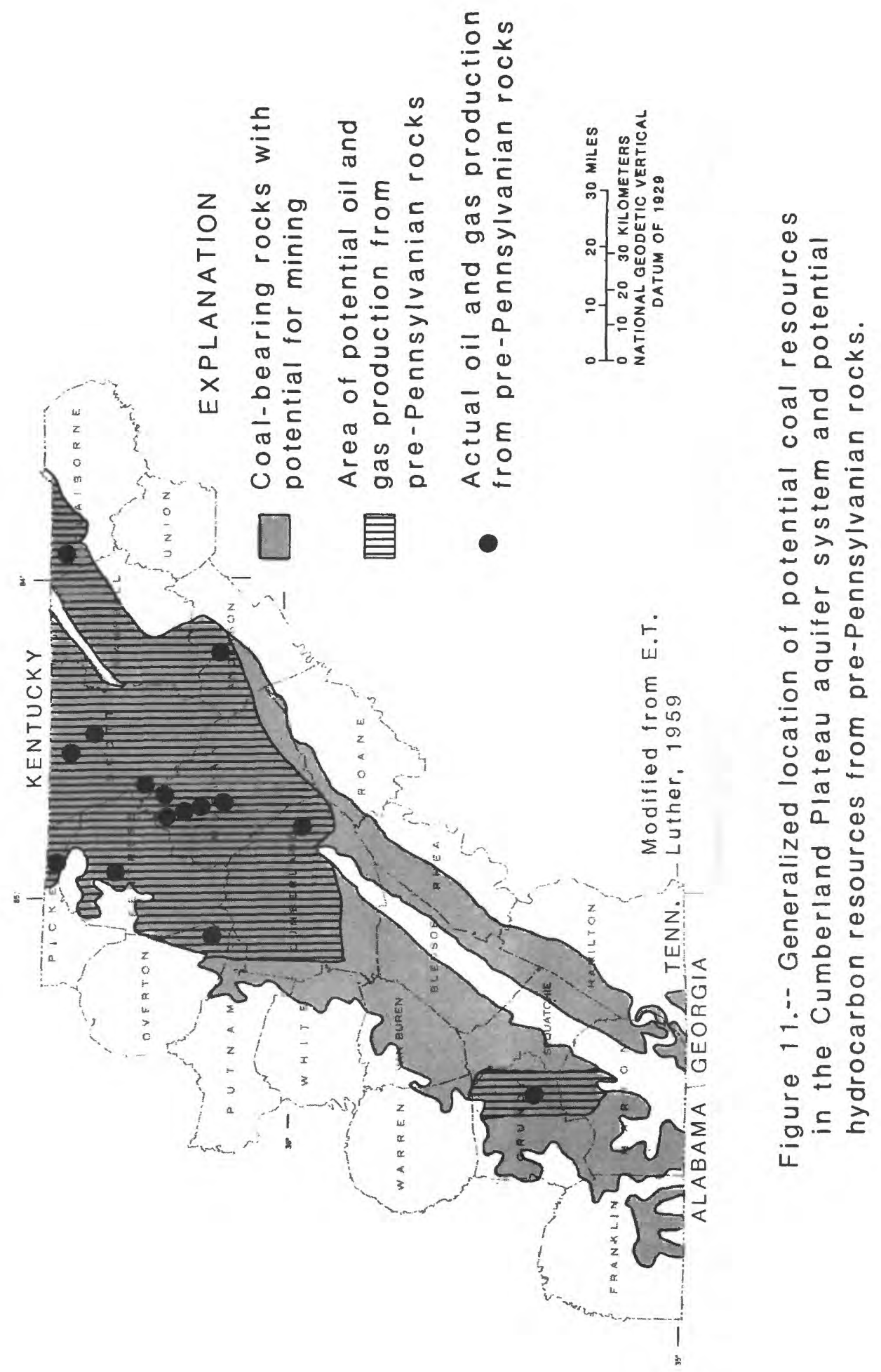




\section{SELECTED REFERENCES}

Born, K.E. , and Burwell, H.B., 1939, Geology and petroleum resources of Clay County, Tennessee: Tennessee Division of Geology Bulletin 47, 188 p.

Burwell, H.B., and Milhous, H.C., 1967a, Oil and gas map Morgan County, Tennessee: Tennessee Division of Geology.

---- 1967b, Oil and gas map Scott County, Tennessee: Tennessee Division of Geology.

Collins, A.G., 1975, Geochemistry of oil field waters: New York, Elsevier Scientific Publishing Company, New York, N.Y., 496 p.

DeBuchananne, G.D., and Richardson, R.M., 1956, Ground-water resources of East Tennessee: Tennessee Division of Geology Bulletin 58, part 1, 393 p.

Englund, K.J., 1966, Geologic map of the Ketchen Quadrangle, Tennessee-Kentucky: U.S. Geological Survey Geologic Quadrangle Map G Q-500.

---- 1969, Geologic map of the Jellico West Quadrangle Kentucky-Tennessee: U.S. Geological Survey Geologic Quadrangle Map GQ-855.

Ferm, J.C., Milici, R.C., and Eason, J.E., and others, 1972, Carboniferous depositional environments in the Cumberland Plateau of southern Tennessee and northern Alabama: Tennessee Division Geology Report Investigations 33, 32 p.

Feth, J.H., and others, 1965, Preliminary map of conterminous United States showing depth to and quality of shallowest ground water containing more than 1,000 parts per million dissolved solids: U.S. Geological Survey Hydrologic Atlas HA-199.

Hack, J.T., 1966, Interpretation of Cumberland escarpment and Highland Rim, southcentral Tennessee and northeast Alabama: U.S. Geological Survey Professional Paper 524-C, 16 p.

Hardeman, W.D., 1966, Geologic map of Tennessee, east-central sheet: Tennessee Division of Geologiy, scale 1:250,000, 1 sheet.

Krieger, R.A., Hatchett, J.L., and Poole, J.L., 1957, Preliminary Survey of the salinewater resources of the United States: U.S. Geological Survey Water-Supply Paper $1374,172 \mathrm{p}$.

Lambert, T.W., and Brown, R.F., 1963, Availability of ground water in Adair, Casey, Clinton, Cumberland, Pulaski, Russell, Taylor, and Wayne counties, Kentucky: U.S. Geological Survey Hydrologic Investigations Atlas HA-35.

Luther, E.T., 1959, The coal reserves of Tennessee: Tennessee Division of Geology Bulletin 63, $294 \mathrm{p}$.

May, R.F., and Maher, S.W., 1979, Minerals in the economy of Tennessee: U.S. Department of Interior, Bureau of Mines, $18 \mathrm{p}$.

Milhous, H.C., 1959, Well logs in Tennessee: Tennessee Division of Geology Bulletin 62, 606 p.

Milici, R.C., Briggs, Garrett, Knox, L.M., Sitterly, P.D., and Statler, A.T., 1979, The Mississippian and Pennsylvanian (Carboniferous) systems in the United States-Tennessee: U.S. Geological Survey Professional Paper 1110-G, 38 p.

Miller, R.A., 1974, The geologic history of Tennessee: Tennessee Division of Geology, Bulletin 74, 63 p.

Miller, R.A., and Maher, S.W., 1972, Geologic evaluation of sanitary landfill sites in Tennessee: Tennessee Division of Geology, Environmental Geology Series No. 1, 38 p.

Nelson, W.A., 1925, The southern Tennessee coal field, included in Bledsoe, Cumberland, Franklin, Grundy, Hamilton, Marion, Putnam, Rhea, Sequatchie, Van Buren, Warren, and White Counties: Tennessee Division Geology Bulletin 33-A, 239 p.

Newcome, Roy, Jr., and Smith, Ollie, Jr., 1958, Ground-water resources of the Cumberland Plateau in Tennessee-A reconnaissance report: Tennessee Division Water Resources Series 1, 72 p. 
Pomerene, J.B., 1964, Geology of the Barthell Quadrangle and part of the Oneida North Quadrangle, Kentucky: U.S. Geological Survey Geologic Quadrangle Map GQ-314.

Rima, D.R., Chase, E.B., and Myers, B.M., 1971, Subsurface waste disposal by means of wells-A selective annotated bibliography: U.S. Geological Survey Water-Supply Paper 2020, 305 p.

Safford, J.M., 1893, The topography, geology, and water supply of Sewanee: Tennessee State Board of Health Bulletin, v. 8, no. 6, p. 89-98.

Smith, J.H., 1978, Geologic map of the Bell Farm Quadrangle and part of the Barthell SW Quadrangle, Mc Greary and Wayne counties, Kentucky: U.S. Geological Survey Geologic Quadrangle Map G Q-1496.

Sprinkle, C.L., 1977 , The Tennessee ground water quality sampling program for FY 1977Progress Report: U.S. Geological Survey, 27 p.

Statler, A.T., Bloss, P., and Zurawski, R.P., 1975, Subsurface information catalog of Tennessee 1866-1974: Tennessee Division of Geology, Bulletin 76, 146 p.

Stearns, R.G., 1954, The Cumberland Plateau overthrust and geology of the Crab Orchard Mountains area, Tennessee: Tennessee Division Geology Bulletin 60, 47 p.

Tennessee Department of Labor, 1981, Annual Report: 97 p.

Wanless, H.R., 1946, Pennsylvanian geology of a part of the Southern Appalachian coal field: Geological Society of America Mernoirs 13, 162 p.

Wilson, C.W., Jr., Jewell, J.W., and Luther, E.T., 1956, Pennsylvanian geology of the Cumberland Plateau: Tennessee Division of Geology, 21 p.

Wilson, J.M., 1965, Ground water resources and geology of Cumberland County, Tennessee: Tennessee Division Water Resources, Water Resources Series 6, 56 p.

Zurawski, Ann, 1978, Summary appraisals of the Nation's ground-water resources-Tennessee Region: U.S. Geological Survey Professional Paper 813-L, 35 p. 